\title{
The Eriugenian Influence in the Summa Halensis: A Synthetic Tradition
}

\begin{abstract}
This paper will consider the question as to whether the thought of Eriugena is a source for the Eastern Christian ideas found in the Summa Halensis. I shall first give a general historical overview of the fate of Eriugenian texts and ideas in this period. Following that, I shall examine the Eriugenian element in an important section of the Parisian Corpus Dionysiacum (Mystical Theology V), and the anonymous Liber de causis primis et secundis, which gives us something of a key to the $13^{\text {th }}$ reading of Eriugena, and helps explain the harshness of later reaction to him. Finally, I shall examine a key example from the Summa in which this debate from the previous five centuries emerges, and conclude. For the purposes of this comparison, I shall focus on one problem, that is, the problem of Eriugena's presentation of the Primordial Causes.
\end{abstract}

\section{Introduction}

When we come to consider the question of the possible influence of Eriugena on Alexander of Hales, we are dealing with a very complex situation, thanks largely to the Condemnations of 1210, 1225 and 1241. We cannot expect to find clear citations of the Periphyseon or any of Eriugena's works. The instruction given in 1225 to find and destroy all the exemplars of the Periphyseon in monastic libraries seems to have been thoroughly executed; the Condemnations of 1241 guaranteed that Eriugena's was not a name one cited except with extreme caution-and usually to condemn him. Significant elements of Eriugena's thought are present in his translations of the Corpus Dionysiacum, and in the editorial work on the Corpus Dionysiacum, ${ }^{1}$ arising

\footnotetext{
1 For studies of the Parisian Corpus Dionysiacum, see Pseudo-Dionysius, Dionysiaca: recueil donnant l'ensemble des traductions latines des ouvrages attribues au Denys de l'areopage, et synopse marquant le valeur de citations presque innombrables allant seules depuis trop longtemps, remises enfin dans leur contexte au moyen d'une nomenclature rendue d'un usage très facile, 2 vols, ed. Philippe Chevallier et al. (Bruges: Desclée De Brouwer, 1937); also Hyacinthe François Dondaine, Le Corpus Dionysien de l'Université de Paris aux XIIIe siécle, Storia e letteratura, 44 (Roma: Edizioni di Storia e letteratura, 1953); also L. Michael Harrington, A Thirteenth Century Textbook of Mystical Theology at the University of Paris: The Mystical Theology of Dionysius the Areopagite in Eriugena's Latin Translation with the Scholia translated by Anastasius the Librarian and Excerpts from Eriugena's Periphyseon, ed. and trans. L. Michael Harrington, Dallas Mediaeval Texts in Translation, 4 (Leuven: Peeters, 2004); also John Scotus Eriugena, Johannis Scoti Eriugenae Expositiones in Ierarchiam coelestem, ed. Jeanne Barbet, Corpus Christianorum Continuatio Mediaevalis, 31 (Turnhout: Brepols, 1975); also Pseudo-Dionysius, La hiérarchie celeste: introduction par René Roques, ed. Günter Heil, trans. Maurice de Gandillac (French), Sources Chrétiennes, 58bis (Paris: Cerf, 1970); also James McEvoy, 'John Scottus Eriu- 
both from the Victorine School and the anonymous hand which inserted large chunks of Eriugena (including also his citations of Greek Fathers) into the 'Maximian' Glosses on the Corpus Dionysiacum following the condemnations of 1225 . $^{2}$ The Vox Aquilae also survived anonymously as did the Clavis Physicae of Honorius of Autun, a resume of the Periphyseon of Eriugena, which did make its way into several versions of the Corpus Dionysiacum without any difficulty, ${ }^{3}$ and those excerpts from the Periphyseon and the Expositiones in Ierarchiam Coelestem which were included in the marginal Gloss on the Dionysian translation. ${ }^{4}$ These Glosses remain remarkably consistent from manuscript to manuscript throughout the transmission of the Corpus Dionysiacum, which means that the works of Dionysius were read on the whole through an Eriugenian lens. On a historical note, the text of Eriugena's Expositiones in Ierarchiam Coelestem was partly reconstructed from Glosses). ${ }^{5}$ Therefore, the area where we are most likely to find Eriugenian influence is in the interpretation of ideas considered 'Greek', as might be expected, since he declared the interpretation of Greek ideas for the benefit of the Latin West to be his life's work. The key concepts are: negative theology, the question of deification and the vision of God, and the question of the Primordial Causes, the prototypa, related as they are to the question of theophany. The Condemnations of 1225 highlight a second aspect of the problem: the texts there condemned for pantheism alongside Eriugena, turn out, on examination, to be a blend of Aristotelian or Avicennian elements, together (in the case of Amaury of Bene) with Eriugenian elements: in fact, this mix of Eriugenian and Avicennian elements with the existing Augustinian paradigm turns out to be crucial to the understanding of the condemnations of Eriugena.

For the remainder of this paper, I shall first give a general historical overview of the fate of Eriugenian texts and ideas. Following that, I shall examine the Eriugenian element in an important section of the Parisian Corpus Dionysiacum (Mystical Theology, Chapter 5), in order to demonstrate how his work was used, when it was used. I shall then look at the anonymous Liber de Causis Primis et Secundis, which gives us something of a key to the $13^{\text {th }}$-century reading of Eriugena, and helps explain the

gena and Thomas Gallus, Commentators on the Mystical theology,' in History and Eschatology in John Scottus Eriugena and His Time, ed. James McEvoy and Michael Dunne (Leuven: University Press, 2002), 183-202. The modern edition of the text of the Corpus Dionysiacum is: Pseudo-Dionysius, Corpus Dionysiacum, 2 vols, ed. Beate Regina Suchla (vol. 1), Günter Heil and Adolf M.Ritter (vol. 2), Patristische Texte und Studien, 33, 36 (Berlin/New York: De Gruyter, 1990 -1). Translated by Colm Luibheid and Paul Rorem, Pseudo-Dionysius: The Complete Works, trans. Colm Luibheid and Paul Rorem, Classics of Western Spirituality (New York: Paulist Press, 1987).

2 See Dondaine, Le Corpus Dionysien, passim; also Harrington, Thirteenth-Century Textbook, 28-32. 3 Honorius Augustodunensis, Clavis Physicae, ed. Paolo Lucentini, Temi e Testi, 21 (Roma: Edizioni di storia e letteratura, 1974); also Paolo Lucentini, Platonismo medievale: Contributi per la Storia dell'Eriugenismo (Firenze: La Nuova Italia, 1979).

4 See Dondaine, Le Corpus Dionysien; Jeanne Barbet, 'Introduction,' in Johannis Scoti Eriugenae Expositiones in Ierarchiam coelestem, XII-XV.

5 See Barbet, 'Introduction,' XII-XV. 
harshness of later reaction to him. Finally, I shall examine a key example from the Summa of Alexander of Hales, in which this debate from the previous five centuries emerges, and conclude. For the purposes of this comparison, I shall focus on one problem, that is, the problem of Eriugena's presentation of the Primordial Causes. He roots it in the Patristic tradition, but as we shall see, by the time we get to the Summa Halensis, the Patristic background has been forgotten, and the strange uses to which the concept could be put are uppermost in the mind of the Halensian Summist to the extent that it is simply condemned out of hand.

\section{Overview}

The history of Eriugena's engagement with the Greek tradition begins with his translation of Pseudo-Dionysius, which makes use of a first effort by Hilduin (according to Théry, probably a collaborative work), ${ }^{6}$ but it is a considerable improvement on the latter. Philosophical terms remain constant throughout, and it is clear that this time, the translator understood the philosophical import of what he was translating. ${ }^{7} \mathrm{He}$ was not interested merely in producing a smooth piece of Latin, but also in understanding himself the thought he was trying to render into Latin from Greek, and thus he brought out the philosophical and theological structure of the text. The final version of his translation was to be the standard Latin version of the Corpus Dionysiacum for the next five centuries, and elements of the Latin vocabulary developed by Eriugena to express the new ideas of Dionysius became standard terminology. (The best example of this is the word 'supernatural', supernaturalis, which is common both in Latin and in English, invented to translate hyperphyseon, a Greek neologism of Dionysius'.) New translations were produced by Sarrazenus and by Grosseteste in the $13^{\text {th }}$ century, and by Traversari in the $15^{\text {th }}$ century, ${ }^{8}$ but all of these were in a sense reworkings of the original, which was Eriugena's: his remained the definitive version, on which others were based, and, significantly, was the stan-

\footnotetext{
6 See Gabriel Théry, Études dionysiennes, vol. 1, Hilduin, traducteur de Denys, Études de philosophie médiévale, 16 (Paris: Vrin, 1932), 101-42.

7 Eriugena has left us an account of his method as a translator in his commentary on the De Celestiis Hierarchiis of Dionysius. In this text, we have first, the lemma from Dionysius, then we have an alternative translation, then we have a brief explanation as to what the piece means, and finally we get an extended commentary on the lemma. See Barbet, 'Introduction,' IX-XI, esp. X, n. 2; also René Roques, “'Valde artificialiter”: le sens d'un contresens,' Annuaire 1969-1970: École pratique des hautes études, Section des sciences religieuses, 77 (1968): 31-72; Vignaux Paul, Roques René, and Jolivet Jean, 'Histoire des anglaises médiévales,' Annuaire 1969-1970: École pratique des hautes études, Section des sciences religieuses, 77 (1968): 308 - 11; Vignaux Paul, Roques René, and Jolivet Jean, 'Histoire des anglaises médiévales,' Annuaire 1970-1971: École pratique des hautes études, Section des sciences religieuses, 78 (1969): 301-5.

8 See Pseudo-Dionysius, Dionysiaca (see above, n. 1) for a description and editions of these translations.
} 
dard version in use in Franciscan houses through the era of high scholasticism. ${ }^{9}$ Eriugena also studied Maximus the Confessor, in order to understand Dionysius better (Maximus was thought to be the Scholiast on the Greek Corpus, although that is now known to be John of Scythopolis), and eventually translated two texts of Maximus': some of the Ambigua ad Iohannem, and the Quaestiones ad Thalassium. In fact, great chunks of Maximus make their way into the Periphyseon, which is intended to enrich the philosophical and theological life of the Western Church with the ideas Eriugena had found so stimulating in the great Byzantine thinkers.

This work of translation and commentary exposed Latin thinkers both to the advances in Christian theology which had emerged in the debates around Chalcedon, and to a more developed stage of Neoplatonic thought than is found in Augustine. The post-Chalcedonian Greek theological tradition makes extensive use of the latest developments in Neoplatonic thought, through Dionysius' adaptation of Proclus' Henads, ${ }^{10}$ but in so doing, it also alters the fundamental metaphysics, since the particularity of the Incarnation inverts the previous prioritisation of the universal over the particular. All this material which he explored in his translations bore fruit in his own most important work, the Periphyseon.

In the centuries which follow, evidence of engagement with Eriugena is sparse: Heiric of Auxerre and Raoul Glaber both used his work, and he was caught up in the Eucharistic controversy of the $11^{\text {th }}$ century because certain works of Ratramnus of Corbie are attributed to him. ${ }^{11}$ During the $12^{\text {th }}$ century, as academic life intensified in both the Cathedral schools and monasteries, we find evidence of more profound engagement with Eriugena, linked to the intense interest in the Greek Fathers which

9 See Dondaine, Le Corpus Dionysien; also Donna Maria Altimari-Adler, 'Dionysiaca Franciscana: materials Dionysian possessed or written by Franciscans or present in manuscripts together with Dionysiaca of Franciscan authorship: Submitted by Donna Maria Altimari-Adler to Professor Emery, Pseudo-Dionysius course' (typescript article, University of Notre Dame, 1995).

10 See Stephen Gersh, From Iamblichus to Eriugena: An Investigation of the Prehistory and Evolution of the Pseudo-Dionysian Tradition, Studien zur Problemgeschichte der antiken und mittelalterlichen Philosophie, 8 (Leiden: Brill, 1978), for a full analysis of this very complex process of transmission. 11 See Paul Edward Dutton, 'Raoul Glaber's De divina quaternitate: An unnoticed reading of Eriugena's translation of the Ambigua of Maximus the Confessor,' Medieval Studies 42 (1980): 431-53; also Ratramnus of Corbie, De corpore et sanguine Domini: texte original et notice bibliographique, ed. J.N. Bakhuizen van den Brink (Amsterdam: North-Holland Pub. Co., 1974), a text long thought to be Eriugenian, and, as such, arousing the interest of James Ussher, in A Discourse of the Religion anciently Professed by the Irish and British (1631), in The Whole Works of the Most Rev. James Ussher, D.D., Lord Archbishop of Armagh, and Primate of All Ireland, vol. 4, ed. Charles Richard Elrington (Dublin: Hodges and Smith; London: Whittaker and Co., 1847), 285. See Édouard Jeauneau, 'Guillaume de Malmesbury, premier éditeur anglaise du Periphyseon,' in Sapientiae doctrina: Mélanges de théologie et de literature médiévales offerts à Dom Hildebrand Bascour O.S.B., ed. Roland Hissette, Guibert Michiels, and Dirk Van den Auweele (Louvain: Abbaye du mont César, 1980), 173. Reprinted in Édouard Jeauneau, Études Érigéniennes (Paris: Etudes Augustiniennes, 1987), 490-521, 514-15. 
Chenu and Lévy have noted: ${ }^{12}$ at the Cathedral School of Chartres, his Platonic cosmology was of interest to people such as Bernard of Chartres. Eriugena is not often cited by name at Chartres, but indirect reference to the works of Eriugena had been usual since Raoul Glaber, at least; Amalric of Bene is a Chartrean, and such elements of his work as we still possess after 1210 indicate serious reading of Eriugena-mistaken, perhaps, but nonetheless extensive, and Amalric cannot have been alone in this. ${ }^{13}$ In Paris, as noted above, the Periphyseon was excerpted as part of the standard Gloss on the Corpus and his translation of the Corpus Dionysiacum played a very important part in the development of the Victorine school. ${ }^{14}$ Honorius of Autun produced the Clavis physicae. In monastic, largely Cistercian circles, William of St Thierry makes abundant use of Eriugena, ${ }^{15}$ and Bernard of Clairvaux knew Eriugena's work, and used it. ${ }^{16}$

All of this was to change, however, during the $13^{\text {th }}$ century, when, in 1210 , he was condemned at the Council of Sens along with David of Dinant and Amalric of Bene (or Chartres), a condemnation for which we do not have acta, as it happens, but the terms of which we know from the letters of Honorius III in 1225, which refer to it. This condemnation was reiterated in 1225 . He was condemned again in 1241, and again in 1681 upon publication of Gale's editio princeps, upon which the Periphyseon was promptly placed on the Index, lingering there until the final abolition of the Index. What is condemned in 1210 is essentially pantheism. The Maximian/Eriugenian claim that the universe is unified in God through the deification of man seemed to some minds at least to be stating that the universe is God. Eriugena intended to reproduce the Maximian Christological cosmology for the benefit of the Western

12 Marie-Dominique Chenu, La Théologie au XIIe siècle (Paris: Vrin, 1966); Antoine Lévy, Le Crée et L'Incréé: Maxime le confesseur et Thomas d'Aquin: aux sources de la querelle palamienne (Paris: Vrin, 2006), 102-8.

13 See Édouard Jeauneau, 'Le renouveau érigénien du XIIe siècle,' in Eriugena redivivus: zur Wirkungsgeschichte seines Denkens im Mittelalter und im Übergang zur Neuzeit: Vorträge des V. Internationalen Eriugena-Colloquiums, Werner-Reimers-Stiftung Bad Homburg, 26.-30. August 1985, ed. Werner Beierwaltes (Heidelberg: Winter, 1987), 26-92, where, due to the lack of citation, he concludes that Eriugena was not much read at Chartres. However, Lévy disagrees: see Lévy, Le Créé et L'incréé, 80. See also Gabriel Théry, Autour du décret de 1210, 2 vols, vol. 1, David de Dinant, vol. 2, Alexandre d'Aphrodise, Bibliothèque thomiste, 6, 7 (Le Saulchoir: Revue des sciences philosophiques et théologiques, 1925-6) and Catherine Capelle, Autour du décret de 1210, vol 3, Amaury de Bène, Bibliothèque thomiste, 16 (Paris: Vrin, 1932), for an account of Amalric of Bène, who was a Chartrean.

14 Dondaine, Le Corpus Dionysien, 35-66.

15 See Jean Déchanet, Guillaume de St. Thierry: Aux sources d'un pensée, Théologie historique, 49 (Paris: Beauchesne, 1978), 63-97.

16 See Étienne Gilson, 'Maxime, Erigène, S. Bernard,' in Aus der Geisteswelt des Mittelalters: Studien und Texte Martin Grabmann zur Vollendung des 60. Lebensjahres von Freunden und Schülern gewidmet, ed Albert Lang, Joseph Lechner, and Michael Schmaus, Beiträge zur Geschichte der Philosophie und Theologie des Mittelalters, Supplementband 3/1 (Münster: Aschendorff, 1935), 188-95 and Étienne Gilson, La Théologie mystique de Saint Bernard, Études de philosophie médiévale, 20 (Paris: Vrin, 1969), $38-42$. 
Church, and, given its strong emphasis on negative theology, pantheism in the strict sense cannot be said to be characteristic of his work read as he clearly intended it to be; but what of the other two?

It is difficult to know for certain, since in their case, the instruction to destroy their works seems to have been followed absolutely. However, we know something of what they said from other works in which theirs were discussed, most notably, in the case of David of Dinant, in a discussion by Albert the Great, as Théry notes throughout his work from 1934. What emerges from these citations is that Amalric was, in fact, influenced by Eriugena, and Eriugena's condemnation came about at least partly as a result of having influenced Amalric, whose main inspiration, however, was not Eriugena, but Joachim of Fiore and his antinomian pneumatology. However, there is a clear connection to Amalric.

With David of Dinant, the situation is a good deal more puzzling. The citations we find in Albert the Great demonstrate no Eriugenian influence at all; they are not even Neoplatonic in any general sense. David is reading Aristotle; he is a dialectician, but in the Aristotelian sense, not the Platonic; he is far closer to Abelard than to Eriugena. In fact, he is a thoroughgoing materialist; anything further from Eriugena's 'objective idealism' would be hard to find. What finally emerges is that David has been reading the early books of Aristotle's Metaphysics, and he has taken on board the Presocratic belief in the unity of the cosmos-a belief which is fundamentally immanentist and materialist. The condemnation of David, then, marks one stage in the battle which raged around the works of Aristotle for most of the $13^{\text {th }}$ century-and that is why Albert the Great took such a keen interest in him. Albert was trying to demonstrate that David had misunderstood Aristotle, and that the latter did not deserve to be excluded from the universities on the basis of David's misunderstanding.

The quarrel had very little to do with Maximus' cosmology as presented by Eriugena; he was guilty by association, since some notion of the unity of the cosmos underpinned both. ${ }^{17}$ But what is really interesting here is the fact that David's materialist cosmic unity could have been read by somebody as Eriugenian; this could only come about if someone is reading Eriugena through an Avicennian lens. There is a great deal of latent Aristotelianism in the later Byzantine Church Fathers, above all in the use Leontius of Byzantium makes of Aristotle in the post-Chalcedonian controversies; ${ }^{18}$ but without some prior knowledge of the later Greek Christian tradition, it would appear that Eriugena's Maximian citations could be made to mean almost anything. The net result was that the most comprehensive and intelligent attempt to understand and represent the thought of the Greek East for centuries was badly frustrated. Only a very select few-e.g. Nicholas of Cusa -succeeded in getting be-

17 See Théry, Autour du décret de 1210, vols 1 and 2, and Capelle, Autour du décret de 1210, vol. 3, for a full discussion of the process and implications of this condemnation.

18 See Leontius of Jerusalem, Complete Works: Leontius of Byzantium; ed. and trans. Brian E. Daley (Oxford: Oxford University Press, 2017). 
yond the bad odour which attended Eriugena to know his thought, which is, in so many respects, Maximus' thought.

\section{The Parisian Corpus Dionysiacum}

The text of Dionysius used at Paris in the $13^{\text {th }}$ century is very complex; the most intensely studied exemplar is Paris, Bibliothéque Nationale, Ms. Lat. 17341, the subject of extensive studies by Dondaine and Harrington. ${ }^{19}$ Both Eriugena's and Sarrazenus' translations are found there, together with Anastasius' Latin translations of the Greek scholia on Dionysius, and long excerpts from the Periphyseon, all interpolated into the text, so that the reader is not reading simply Dionysius, but, as Harrington has observed, also seven centuries of commentary and interpretation as well. The Corpus Dionysiacum is a text, or set of texts, which requires great hermeneutical subtlety in the reading and interpretation of it-that is one of the things which makes it so difficult to translate-and the commentary tradition as found in the Glosses alone, is extraordinarily rich. To a certain extent, the increasingly analytic approach of the burgeoning scholastic movement ran counter to the hermeneutical subtleties of the commentary on the Corpus, and this is perhaps another element which gets Eriugena into trouble eventually, since in order to read Eriugena, a willingness to immerse oneself in and sympathise with his particular style and diction is necessary: in that regard he resembles Plotinus. It is a style of doing philosophy to which monastic life is very suited: the slow process of the lectio divina allows the text to release its richness gradually in a way that the more agonistic style of the scholastic quaestio forbids.

The excerpts from the Periphyseon found in the text of the Corpus seem to have been selected, on the whole, for the light they cast on the Greek scholia: these are rich in examples from Greek literature and theology which must have been very puzzling for a Latin reader of the $13^{\text {th }}$ century lacking access to the full resources of Greek culture, but Eriugena's explanations of the same material do make it much more intelligible to a Latin mind-set: see, for example, the Scholiasts' explanations of the terms kataphatike and apophatike as compared with Eriugena's. ${ }^{20}$ The most significant group of concepts is that surrounding the questions of the knowledge of God by the creature, God's knowledge of Himself, and God's knowledge of creatures.

It is a commonplace of negative theology that God is known in his effects, but the effects are not God, so God in himself is not known in this way. Combined with this in Greek theology is Gregory of Nyssa's emphasis on God's infinity, so that God could never be known fully by a finite creature-simply as a matter of

19 See Dondaine, Le Corpus Dionysien; Harrington, A Thirteenth-Century Textbook.

20 See Harrington, A Thirteenth-Century Textbook, 88-91 (for the Greek Scholiast in Paris, Bibliothèque Nationale de France, Lat. 17341) and 81 (for Eriugena's explanation of the same material). 
logic. The finite cannot encompass the infinite. However, for Pseudo-Dionysius, the 'effects' by which God is known are not the ontological realities that Aquinas was later to work into the Five Ways, but the words of Scripture. Scripture is what Dionysius means by 'Theology': thus the Mystical Theology is a hermeneutical exercise. This is, so to speak, the ultimate reading of Scripture, the hard reading. Ultimately, the goal of all theology and philosophy is contemplation, which is not propositional nor does it assert anything at all, nor does it deny anything: it is 'the cloud of unknowing'. One can see the monastic, contemplative approach to Scripture lying behind this. It is full of paradox: negation says more than affirmation, darkness is brighter than light, ultimate Wisdom is unknowing...The Scholiasts carefully unpack and explain all of this for the benefits of the reader, and Eriugena improves on the Scholiasts.

In the Gloss on Chapter 5 of the Mystical Theology, the glossator has inserted a long excerpt from the Periphyseon, Book 2, including in the latter part of the citation elements drawn from Gregory of Nyssa (whom Eriugena confused with Gregory Nazianzen):

So when we ask of this or that "What is it?", does it not appear to you that we are seeking for nothing else but a substance which either has been defined or is capable of being defined? (...) If, then, no wise man asks of all essence in general what it is, since it cannot be defined except in terms of the circumstances which circumscribe it, so to speak within limits, I mean place and time, quantity and quality, relation, connection, rest, motion, condition and the other accidents by which the substance itself by reason of being subject, unknown and indefinable through itself, is shown only as subsisting, but not as to what it is, what man learned in the discipline of the divine word would presume to inquire of the Divine Substance what it is, when he understands very well concerning it that it cannot be defined, and is not any of the things that are, and surpasses all things that can be defined? (...) let every soul refrain from rashly rushing into any speech of the matters that concern God, to define him thereby, but let her reverence in silence only the truth of the Divine Essence, ineffable and beyond understanding, and the highest wisdom of all. If then, there is no one, even among the wisest, who can know the reasons of existing things, as those reasons were first established, who would dare to find in anything a definition of God? ${ }^{21}$

21 Harrington, A Thirteenth-Century Textbook, 109, citing the text of Eriugena from the Periphyseon, Book 2. See Iohannis Scotti seu Eriugenaei, Periphyseon, Books I-V, 5 vols, ed. Édouard Jeauneau, Corpus Christianorum Continuatio Mediaevalis (CCCM), 161-5 (Turnhout: Brepols, 1996-2003), 2:136.24-138.13. Translation: Eriugena, Periphyseon (The Division of Nature), trans. I.P. Sheldon-Williams (Books I-V), (Books IV-V) revised by John O'Meara, Cahiers d'études médiévales (Montréal, Québec), Cahier special, 3 (Montreal: Bellarmin; Washington: Dumbarton Oaks, 1987); also Joannis Scoti opera quae supersunt omnia, ed. Heinrich Joseph Floss (PL 122:439-1022); Iohannis Scotti Eriugenae, Periphyseon (De Divisione Naturae), 4 vols, Books I-III ed. Inglis Patrick Sheldon-Williams, Book IV ed. Édouard Jeauneau, Scriptores latini Hiberniae 7, 9, 11, 13 (Dublin: Dublin Institute for Advanced Studies, 1968 -95). Harrington provides his own translation; I have used the Sheldon-Williams version. 
This is certainly very startling: that God is not ultimately comprehended by the human intellect is, as noted, a commonplace of not only Christian Neoplatonism, but also of pagan Neoplatonism: Plotinus says it, Proclus says it, Damascius says it. Indeed, we could trace it back to Plato; in Christianity, we find it in St Paul and St John's works: what he is in himself is not known, because the finite cannot compass the infinite. But to say that creatures cannot know each other, let alone that God does not know his creatures seems to push the concept into absurdity. What is Eriugena doing here?

Eriugena had already argued that the essence even of created things is ultimately unknown as to what it is in Book 1 of the Periphyseon, where we find ${ }^{22}$ the Aristotelian Categories blended with the periochae, or 'circumstances', although the periochae are usually a hermeneutical structure, which can ultimately be traced, as a hermeneutical device, to Servius' commentary on Virgil. ${ }^{23}$. Commonly associated in antiquity with rhetorical, legal proofs, had come to be employed as a kind of key in the exegesis of texts, initially by Servius, and then by generations of HibernoLatin biblical commentators ${ }^{24}$ finally, it would appear, being fixed as the form of the accessus in the circle around Eriugena and Remigius of Auxerre. They have been adapted here for a philosophical purpose; they indicate OYCIA (ousia), in itself incomprehensible: 'they are seen to be around it.' Something can be understood about ousia from the categories of place, quantity, situation and time. The congruence of these indicates an ousia which itself is none of them; it a useful way of delimiting essence without having to pin down what it is. The periochae function as a sort of accessus ad essentiam - they do not necessarily comprehend it any more than an accessus comprehends its text.

This understanding of essence as incomprehensible in itself underpins the citation incorporated into the Corpus. He is arguing that what we consider 'knowledge' is normally our interpretation of our sensory experience, dependent on circumstance, and that is summed up by the Categories, identified with the Circumstantiae of Servius. But circumstance does not touch the essence of a thing; a real thing cannot simply be the sum total of its circumstances. Thus, there is something irreducibly mysterious about any being whatever-because, in the final analysis, all things come from God, and their divine origin is a mystery. At this point, we revert to the Eriugenian Primordial Causes (which have their origin in Augustine's rationes seminales, ultimately a Stoic structure): anything at all that exists has a Primordial Cause, which is in God. What it is, is ultimately its Primordial Cause, which is not accessible

22 Eriugena, Periphyseon I, 471C-472B (CCCM 161).

23 Servius, Servii Grammatici qvi fervntvr in Vergilii carmina commentarii, 4 vols, ed. Georg Thilo and Hermann Hagen (Leipzig: B.G. Tevbneri, 1881), 1:1: 'In exponendis auctoribus haec consideranda sunt: poetae vita, titulus operis, qualitas carminis, scribentis intentio, numerus librorum, ordo librorum, explanatio.'

24 See Pádraig Ó Néill, 'The Old Irish Treatise on the Psalter and its Hiberno-Latin Background,' Ériu 30 (1979): $148-64$. 
to our senses. The glossator of the Corpus, quotes Eriugena on the ancients at this point, ${ }^{25}$ where Eriugena observes that the ancients taught that what is accessible to the senses is not known, since it is unstable, reiterating Plato's doctrine that knowledge in the true sense can only be of stable things-that is, of the Forms in their transcendence, which cannot be bodily knowledge. So what we think of as knowledge is bodily, entering by the senses, and therefore it can only ever be circumstantial: it cannot access the Primordial Causes, which is to say the essences of things, things as they really are in God: ousia. Anything that is a different kind of wisdom will not appear to us to be 'knowledge', but some other kind of intuition or understanding.

What about God's knowledge of himself, or of creatures? If what we think of as knowledge is circumstantial and bodily-well, God is pure spirit, and so, as he is in himself, he cannot have this knowledge. But also, he is infinite, unencompassable, even by himself. But the Primordial Causes of creature are also found in God, and to that extent, they participate in his divinity, including, presumably, his infinity, and to that extent, they are also unencompassable. This is also an aspect of the freedom of creatures: they are not simply puppets, but have real capacity to act autonomously. Paradoxically, the creature most like God is the one with the capacity also to reject him.

Clearly, these are difficult ideas. Understood as part of a rich hermeneutic applied to the reading of a very complex text, they facilitate meditation on some of the greatest mysteries of the Christian faith. However, taken out of context, and juxtaposed with philosophy emerging from a very different tradition, they appear startling, opposed to Christian tradition, and this is what happens when Eriugena begins to be read in conjunction with Avicenna. As Lévy has pointed out, it is not necessary to read Eriugena as saying the same thing as Avicenna, but it is very easy to do so. ${ }^{26}$ This is what we see happening in the anonymous Liber de Causis Primis et Secundis, and it is precisely this complex of ideas around the knowledge of God (in theophany) and the presence of intermediaries between God as he is in himself and creation (in theophany, also primordial causes) which lead ultimately to the condemnations of 1241 and some sharp remarks in the Summa Halensis on Eriugena's Primordial Causes.

\section{Avicenna and Eriugena}

During the late $12^{\text {th }}$ and early $13^{\text {th }}$ centuries, Avicenna's reading of Aristotle, heavily Neoplatonised, introduced ideas into the Western philosophical canon which were sufficiently similar to the philosophical ideas introduced by Eriugena from the Greek theological tradition, at least in terms of philosophical structure, to be syncret-

25 Harrington, A Thirteenth-Century Textbook, 109.

26 Lévy, Le Créé et L'Incréé. 
ically combined with them. At the origin of both lies Proclus, in fact. The translation of the Liber de Causis introduced Proclus by far more direct means, ${ }^{27}$ but it was thought to be Aristotelian. That the Liber de Causis could be accepted as a work of Aristotle's tells us something about what the earlier part of the $13^{\text {th }}$ century expected from Aristotelian theology: apparently, it expected Procline Neoplatonism, thanks largely to these mistaken attributions of Neoplatonic texts to Aristotle: the Arabic tradition of the Liber de Causis, ascribed to Aristotle, and the Plotinian Theology of Aristotle, ascribed to Aristotle by Al Kindi, along with the Avicennian reading of Aristotle. This Neoplatonic reading of Aristotle combined with Eriugena could produce a kind of philosophia perennis which carried philosophy in a direction quite inimical to orthodox Christian theology. The anonymous Liber de Causis Primis et Secundis, ${ }^{28}$ discussed below, makes this very clear. Eriugena had prioritised the Greek Fathers: the Periphyseon is on one level an extended argument between the Augustinian position, as argued by the Alumnus and the Dionysian-Maximian, as argued by the Nutritor. ${ }^{29}$ Read in the light of a knowledge of Maximian theology, Eriugena is orthodox-given perhaps, to literary or poetical similes, open to misinterpretation, but not necessarily implying such. The Western Christian reaction to Eriugena is normally taken by Eastern Christian scholars as yet one more example of the woeful failure of Western Christianity to understand the Eastern tradition, and on one level, this is true. However, Eriugena read in combination with Avicenna which no Orthodox scholar would do, but was clearly happening at this time, could also take one right back to late Hellenistic Neoplatonism, and on to a system of thought diverging very sharply from Christian theology. This may help to explain why Eriugena comes under fire to such an extent in the early $13^{\text {th }}$ century. The condemnations of 1241 , following on from those of 1210 and 1225, have in view a very specific conjunction of influences -Arab, Greek and Aristotelian-which they want to break up. Albert the Great set himself to disentangle Aristotle from all of this, in order to demonstrate that Aristotle was worthy of serious consideration by a Christian, but the question as to how the Greek Fathers could be integrated into the Western tradition was not directly addressed. As Chenu has pointed out, the Condemnations of 1241 indicate a profound discomfort with orthodox Greek Christian thought, but clearly nobody can condemn

27 See Liber de causis: Das Buch von den Ursachen, mit einer Einleitung von Rolf Schönberger, trans. Andreas Schönfeld, Philosophische Bibliothek, 553 (Hamburg: Meiner, 2003).

28 Liber de Causis Primis et Secundis et de fluxu eorum, ed. Roland de Vaux, in Roland de Vaux, Notes et Textes sur L'Avicennisme Latin aux confins des XII ${ }^{e}$-XIII ${ }^{e}$ siècles, Bibliothèque thomiste, 20 (Paris: Vrin, 1934).

29 Even that is controversial, however, since a number of distinguished Eriugenian scholars (e.g. Édouard Jeauneau) argue that Eriugena represents in reality 'an Augustinian fabric with Greek motifs stitched into it': see Édouard Jeauneau, 'Pseudo-Dionysius, Gregory of Nyssa, and Maximus the Confessor in the Works of John Scottus Eriugena,' in Carolingian Essays: Andrew W. Mellon lectures in early Christian studies, ed. Uta-Renate Blumenthal (Washington, DC: The Catholic University of America Press, 1983), 138-49. Reprinted in Jeauneau, Études Érigéniennes, 175-87. 
so august a figure as Dionysius the Areopagite or his followers. Yet Eriugena, being a 'modern', is a different prospect.

\section{The Liber de Causis Primis et Secundus}

The reasons for this extreme concern with potentially pantheistic elements in 1210, and with that and many other propositions also in 1241, can be understood on reading the Liber de Causis Primis et Secundis. It consists of a mixture of Avicennian, Augustinian and Eriugenian elements, but, as the editor observes, specifically Christian references are all carefully filtered out of both the Augustinian and Eriugenian material, in order to make the work a purely rational, philosophical text. ${ }^{30}$ Clearly what is at work in the Liber is an active engagement with Avicenna (whose Neoplatonised reading of Aristotle made the Philosopher a much easier prospect for scholars trained in the profoundly Augustinian schools of the early Middle Ages) and an attempt to combine him with the existing Augustinian paradigm, into which Eriugena is also stitched. In the edition published in 1508 by the Augustinians at Venice, this is called Liber Avicenne in primis et secundis substantiis et de fluxu entis-it was thought to be by Avicenna. However, even the most cursory reading of the text reveals elements which are manifestly not Avicennian: there are frequent references to Dionysius the Areopagite; the authority of Augustine is invoked; the name of Gregory of Nyssa is brought into play also; and there is distinctly non-Avicennian vocabulary in use (the author refers to theophaniae and vita prima). The text is composed as a series of extracts drawn from various auctoritates, juxtaposed one against the other in order to teach a certain philosophical doctrine. But this is not a simple process of redaction: the author edits his selected texts very carefully in order to guide the discussion to the desired outcome. The authorities actually mentioned are the great ones: Augustine, Dionysius, Gregory of Nyssa (often Eriugena in the case of these latter two), the Philosopher, i.e. Aristotle, although in a couple of cases the author actually cites Avicenna as the 'Philosopher'. This practice is not, however, unique to the Liber. In the Summa Halensis, Aristotle and Avicenna are both called the 'Philosopher'. The author knows the Liber de Causis, and quotes Aristotle according to the oldest translation from Greek into Latin, and seems to have drawn some material from Alexander of Aphrodisias and Alfarabi. Books 1 and 2 of the Periphyseon underpin much of the text, although Eriugena is never mentioned by name-his thought appears occasionally under the name of Gregory of Nyssa or Pseudo-Dionysius.

It dates from the first quarter of the $13^{\text {th }}$ century: the textual references, the manuscript tradition, the paucity of reference to Aristotle, and the extensive use of Eriugena all indicate a date of composition some time then. It would be difficult to find a

30 Liber de Causis Primis et Secundis, 72-9. 
text making such free use of the Periphyseon following 1225. The subject of the text is Neoplatonic emanationism, in which the angelic hierarchies of Dionysius and the primordial causes of Eriugena are all reduced to the Intelligences of the spheres of Avicenna. Throughout the Liber, we find Avicenna and Eriugena tightly interwoven -see, for example, Chapter 8, where the author's discussion of motion and life, and its relation to essence and being, shifts seamlessly from Avicenna to Eriugena and back: specifically Christian elements are simply not present in the discussion.

In order to appreciate how the author of the Liber is working with Eriugena, it is useful to compare specific texts. In Chapter 2 of the Liber, we find:

We say then, that those things which are made are co-eternal with God, but are not absolutely coeternal with God. Coeternal indeed because nothing was done by Wisdom without the Primordial Causes made in it. ${ }^{31}$

Compare this with:

$\mathrm{N}$ : So the principal causes of all things are co-eternal with God (...) A: They are not in all respects co-eternal. For while we believe that the Son is in all respects co-eternal with the Father, those things which the Father makes in the Son, we call co-eternal with the Son, but not in all respects co-eternal. They are co-eternal in the sense that the Son was never without the Primordial Causes of natures created in Him. ${ }^{32}$

The question with which the author is concerned here is that of the Primordial Causes: are they absolutely equal to God? If so, then we are dealing with a variety of pantheism here-certainly, some kind of emanationism. The really fundamental question is how a created work can relate to its creator: what is the nature of the relationship? Is the world really separate from God? Or is it God-is God really separate, beyond the world? The answer given here is the characteristic Neoplatonic one: it is and it is not. It proceeds from God in its effects, which are what we know (which is a form of separation); but it also remains in him, which is why Eriugena says essences are unknown: they are that aspect of reality which is always with God, Who is unknown as to what he is (but not that he is). It proceeds, but does not detach. Eriugena, along with the whole Greek tradition, wants to say that the material, the phenomenal, is contained within the spiritual, and never detaches from it, and the Neoplatonic structure of Procession and Return permits that. Avicenna retains this Neoplatonic ontology in his reading of Aristotle, but the role of the Logos, the essen-

31 Liber de Causis Primis et Secundis, 92: 'Dicimus ergo quod illa que facta sunt deo coeterna sunt, non omnino tamen deo coeterna. Coeterna quidem quia numquam fuit sapientia sine primordialibus rerum causis in se factis.'

32 Eriugena, Periphyseon II, 561C (CCCM 162): 'Sequitur haec omnia, Deum Patrem dico et Verbum rerumque causas in eo factas, coaeterna esse ( ... ) Non omnino coaeterna sunt. Nam filium Patri coaeterna esse omnino credimus, ea vero qui facit Pater in Filio, coeterna Filio esse dicimus non autem omnino coaeterna: coaeterna quidem qui nunquam fuit Filius sine primordialibus naturarum causis in se factis.' 
tial intermediary, is not as evident. It looks as though the author of the Liber is trying to reintroduce the Logos, but as a philosophical rather than a Scriptural, concept, by calling it 'Wisdom'; although the identification of Christ with Wisdom is a mediaeval exegetical commonplace, and one needs to be careful about reading too much into this.

\section{The author then follows on with:}

That they are not absolutely coeternal is made certain by this, and is this, that the first cause of things, because of the infinity of its diffusion, and its incomprehensible altitude, and the excellence of its ineffable purity, is not perceived by any intellect, except that which formed them in the beginning. For they are known from their effects, that is, their processions into intelligible forms, but only that they are, not what they are, and thus they originate in the principal causes in those things of which they are causes, and they do not leave the Beginning, that is Wisdom, in which they are made, and, as I say, in themselves, they remain invisible, hiding their excellence in darkness, not ceasing to appear in their effects as in the light of knowledge. ${ }^{33}$

\section{Compare this with:}

For they are called "abyss" on account of their unfathomable depth and their infinite diffusion through all things, which is perceived by no sense, and comprehended by no intellect, and they have earned the name of 'darkness' because of the ineffable excellence of their purity (...) Thus there was darkness over the abyss of the Primordial Causes darkness is still over this abyss because it is perceived by no intellect except that which formed it in the beginning. But from its effect, that is, its procession into intelligible forms, it is known only that it is, not what it is. ${ }^{34}$

And

The principal causes, then, both proceed into the things of which they are the causes, and at the same time, do not depart from their principle, that is, the Wisdom of the Father, in which they are created, and if I may so express it, just as remaining in themselves invisibly by being eter-

33 Liber de Causis Primis et Secundis, 92-3: 'Quod autem non omnino coaeterna, certificatur in hoc, et est hoc quia cause rerum prime propter infinitam sui diffusionem et incomprehensibilem altitudinem et ineffabilis puritatis excellentiam nullo percipiuntur intellectu, except illo qui eas inprincipio formavit. Ex effectibus autem earum, hoc est ex processionibus in formas intelligibiles, cognoscitur solummod quia sunt, non quid sunt, et sic principales cause in ea quorum sunt cause proveniunt, et principium, id est sapientiam, in qua condita sunt, non reliquunt, et ut ita dicam in se ipsis permanent invisibiles, tenebris excellentiae sue abscondite, in effectibus suis, veluti in quondam lucem cognitionis prolate non cessant apparere.'

34 Eriugena, Periphyseon II, 550C-551 A (CCCM 162): 'Abyssus enim dicuntur propter earum incomprehensibilem altitudinem, infinitamque sui per omnia diffusionem, quae nullo percipitur sensu, nullo comprehenditur intellectu, praeque ineffabilis suae puritatis excellentia tenebrarum nominee appellari meruerunt ( ... ) Et adhuc tenebrae sunt super hanc abyssum, quia nulla percipitur intellectu, eo excepto qui eam in principio formavit. Ex effectibus autem, hoc est processionibus eius in intelligibiles formas cognoscitur solummodo quia est, non autem intelligitur quod est.' 
nally concealed in the darkness of their excellence, do not cease to appear by being brought forth into the light, as it were, of knowledge in their effects. ${ }^{35}$

These passages develop the question of Procession and Remaining further. What proceeds is known to our intellect, what remains cannot be. What proceeds is the effects by which a thing is known through circumstances ('Categories', or Circumstantiae), but what it really is, its essence, remains unknown. It is notable that Eriugena gives these ideas a distinctively Christian, theological slant, in his use of the word 'Father' for God, and all of his thought is contained with a fundamentally Trinitarian structure. The Author of the Liber, on the other hand, has tried to move the whole discourse onto a purely philosophical plane, but treating of Christian, Trinitarian discourse as purely philosophical analogy will alter the nature of what is under discussion fundamentally, since either multiplicity (three) or unity (One God) can be retained logically speaking, but not both.

A very important Eriugenian point is subsequently reiterated:

every creature begins to be, because it was when it was not. For it is not true eternity to begin in some way. ${ }^{36}$

Compare this with:

But every creature begins to be because there was a time when it was not. It was in its causes when it was not in its effects. Therefore it is not in all respects coeternal with true eternity. ${ }^{37}$ Again, the subordinate place of the Primordial Causes is reiterated. Although located in the Word, and thus enjoying a species of eternity, they do have a beginning in time, and therefore are not the same as God, who does not.

These citations, clearly, deal with the Primordial Causes, which, together with the question of the knowledge of God, was to be a very vexed question for Alexander of Hales. The Eriugenian Primordial Causes have deep roots in the philosophical tradition, going back to Augustine's seminal reasons. What they are, in the end, is the Forms: the eternal Idea of any thing in the mind of God, before it comes to be in space and time, and this is a perfectly standard idea in both Eastern and Western Christian metaphysics. However, as represented here, they seem to indicate another level of divinity, some kind of World Soul, or indeed pantheism, and this is what is

35 Eriugena, Periphyseon II, 552 A (CCCM 162): 'Principales itaque causae et in ea quorum causae sunt proveniunt et principium, id est sapientiam Patris, in qua factae sunt, non relinquunt et, ut sic dicam, in seipsis permanentes invisibiles, tenebris suae excellentiae semper absconditae, in effectibus suis veluti in quamdam lucem cognitionis prolatae, non cessant apparere.'

36 Liber de Causis Primis et Secundis, 93: 'omnis creatura incipit esse, quoniam erat quando non erat. Non est autem vere eternitatis modo quodam incipere esse ( ... ).'

37 Eriugena, Periphyseon II, 562 A (PL 122:562 A): ‘Omnis enim creatura incipit esse quia erat quando non erat: erat in causis quando non erat in effectibus. Non omnino igitur vere aeternitati coaeterna est.' 
condemned in the Summa Halensis. As the Eriugenian theophany is merely intended as a way to understand how one's knowledge of God could be eternally growing, a reiteration of Gregory of Nyssa's 'From Glory into Glory', but was misunderstood as claiming that one could never know God, but only some kind of reflection of Him, so too this is misunderstood as pantheism.

\section{The Summa Halensis}

When we come to look at the Summa Halensis, we find that the debate concerning Avicennian readings of Eriugena and of his Greek sources has had its effect. Alexander poses the question: 'An creari sit aliquod creatum ut medium inter Creatorem and creaturam?'38 The formulation is lapidary: either a thing is created or it is not. The Summa Halensis does focus on the Divine Ideas throughout, very much so, but what it rejects from the earlier tradition is the idea of these Divine Ideas as mediators between created being and God: it is the idea of mediation that is attacked, as it is in 1241 in regard to theophany as well. Partly this is because of a different metaphysics of being: for the Byzantine tradition, being is that which exists in space and time; thus, God is beyond being. If God creates, He draws things from non-being into being-but He must have the idea of them first, so some kind of pre-being blueprint is necessary, if creation is to be conceived at all. But here we seem to be dealing with a more absolute identification of being with existence as such. The mental categories of real in space and time and not-yet-real, as an idea of God's, on which Eriugena plays, are here hardened into definite and separate structures of Creator and created being: only one or the other is possible.

The Summa makes this very clear in the contra:

Omne quod est, aut est Creator aut creatura; ergo supervacuum est ponere medium inter haec, immo pro damnata haeresi in concilio Senonensi quod dicitur in libro Periphyseon, in quo dicebatur quod ideae erant medium inter Creatorem et creaturam; (...).

Respondendum est quod non ponitur medium inter Creatorem et creaturam: non enim est medium inter ens ab alio et ens non ab alio. ${ }^{39}$

38 Alexander of Hales, Doctoris irrefragabilis Alexandri de Hales Ordinis minorum Summa theologica (SH), 4 vols (Quaracchi: Collegium S. Bonaventurae: 1924-48), Vol II, In1, Tr1, S2, Q2, M1, C3 (n. 43) p. 52.

39 SH II, In1, Tr1, S2, Q2, M1, C3 (n. 43) p. 52: [Everything that is is either the Creator or a creature: therefore it is redundant to place a medium between these, as indeed was the heresy condemned at the Council of Sens, of that which is said in the Periphyseon, in which it is said that the Ideas were a medium between the Creator and the creature; ( ... ).

Response: A medium is not to be placed between the Creator and the creature, for there is no medium between a being from something and a being not from something]. 
The Summa here is reacting to a section of Periphyseon III: 'Then, descending from the Primordial Causes which occupy a kind of intermediate position between God and the creature (...) He is made in his effects, and openly revealed in their theophanies. ${ }^{40}$ One can certainly sympathise with the Summist's impatience with that quamdam: what does it mean to say, 'kind of, as it were, a medium'? Going further, what is a 'medium' between God and His creation anyhow? But the fundamental problem which Eriugena is trying to address remains: What is it to create? What is it for God to create? What is the link between Creator and created? Eriugena's use of quamdam here is highly significant: he is signalling that a link of some sort there must be, and that this is one way of talking about it. But clearly, this is open to all sorts of interpretation, including some very strange ones. The Summist, in attempting to clear up the confusion which Eriugenian Avicennianism was causing, has simply dismissed the question-at least here.

\section{Conclusion}

The examples discussed here seem to indicate that Eriugena's influence was largely negative, in that he was somebody against whom Alexander and the authors of the Summa reacted. This is not necessarily so, but that it appears to be so is largely a function of how theology and philosophy were written for centuries: something taken as true was simply absorbed into the tradition without citation (as, for example, Eriugena's coinages for Dionysius' hyper-terms), whereas something rejected is sharply noted and criticised. What the controversy around the Primordial Causes does indicate, however, is the extent to which Eriugena was a significant author: his were ideas which still had to be considered. Undoubtedly, further detailed work on key Eriugenian concepts-deification, microcosmism (a very significant idea in the Summa Halensis), the living unity of the Universe-would indicate that his were ideas with which the authors of this era engaged seriously and in great depth, albeit anonymously.

40 Eriugena, Periphyseon III, 683 A-B (CCCM 163): 'Deinde ex primordialibus causis, quae medietatem quamdam inter Deum et creaturam obtinent, hoc est inter illam ineffabilem superessentialitatem super omnem intellectum et manifestam substantialiter naturam.' 
